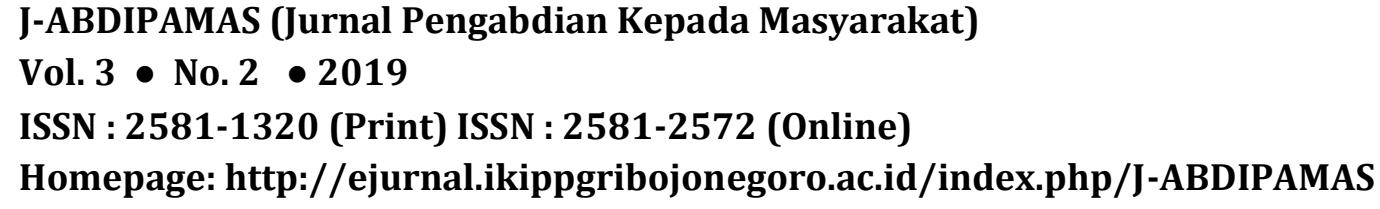

\title{
PENDAMPINGAN PENGEMBANGAN MEDIA PEMBELAJARAN SAINS SEKOLAH DASAR UNTUK PARA GURU
}

\author{
Elisabeth Pratidhina ${ }^{1}$, Herwinarso ${ }^{2}$, Jane Koswojo ${ }^{3}$, Hady Sutris Winarlim ${ }^{4}$ \\ ${ }^{1}$ Universitas Katolik Widya Mandala Surabaya. Email: elisa.founda@ukwms.ac.id \\ 2 Universitas Katolik Widya Mandala Surabaya. Email: herwinarso@ukwms.ac.id \\ 3 Universitas Katolik Widya Mandala Surabaya. Email: janekoswojo@ukwms.ac.id \\ ${ }^{4}$ Universitas Katolik Widya Mandala Surabaya. Email: hady@ukwms.ac.id
}

\begin{abstract}
A program to train Elementary School teacher in developing science learning media has been conducted in Dapena Elementary School and St Theresia II Catholic Elementary School, Surabaya. The training aims to improve teachers' skills on making science learning media and teachers' understanding on science concepts. In this training, teachers have made science learning media on the themes of air, electricity, and energy. According to pre- and post-test result analysis, teachers gain knowledge on scientific approach learning and science concept related to air, electricity, and energy themes. The calculated gain of average can be categorized as medium gain. In addition, according to the evaluation by participants, the program has been conducted very well.
\end{abstract}

Keywords: learning media, science, elementary school, teacher training program

\begin{abstract}
ABSTRAK
Sebuah program pendampingan guru-guru Sekolah Dasar (SD) untuk mengembangkan media pembelajaran sains telah dilaksanakan di SD Dapena dan SD Katolik St. Theresia II Surabaya. Tujuan pendampingan ini adalah untuk meningkatkan keterampilan dalam membuat media pembelajaran sains dan memperdalam penguasaan konsep sains para guru SD. Pada pelatihan ini, para guru telah membuat media pembelajaran sains dalam tema Udara, Listrik, dan Energi. Berdasarkan analisis hasil pre- dan post-test, para guru mengalami peningkatan pembelajaran dengan pendekatan saintifik dan konsep sains terkait tema Udara, Listrik, dan Energi. Nilai gain of average yang diperoleh pada perbandingan rata-rata pre-dan post-test dapat dikategorikan sebagai peningkatan sedang. Selain itu, berdasarkan evaluasi oleh para peserta, program ini telah terlaksana dengan sangat baik.
\end{abstract}

Kata Kunci: media pembelajaran, sains, sekolah dasar, program pelatihan guru

\section{PENDAHULUAN}

Untuk mendukung kemajuan teknologi, sains merupakan ilmu dasar yang penting. Oleh karenanya, pendidikan sains menjadi perhatian khusus banyak negara di dunia. Di Indonesia sendiri, muatan pendidikan sains sudah mulai dimasukan sejak pendidikan dasar.

Literasi sains di Indonesia masih tergolong rendah apabila dibandingkan dengan negara-negara lain. Menurut penilaian Programme for International Student Assessment (PISA) tahun 2015, prestasi anak-anak Indonesia di bidang sains menempati urutan ke62 dari 70 negara yang berpartisipasi (OECD, 2018). Rendahnya prestasi dan literasi di 
bidang sains bisa jadi merupakan akibat dari rendahnya ketertarikan para peserta didik dalam mempelajari sains. Strategi pembelajaran yang tepat diperlukan untuk dapat menarik minat para peserta didik dalam belajar sains khususnya pada level sekolah dasar dan menengah. Meskipun di level sekolah dasar (SD), sains bukanlah mata pelajaran yang berdiri sendiri, tema-tema sains banyak ada di materi pembelajaran. Pembelajaran tema sains di SD merupakan kesempatan untuk menanamkan ketertarikan peserta didik terhadap ilmu sains.

Salah satu pendekatan yang direkomendasikan pada Kurikulum 2013 adalah pendekatan saintifik (Permendikbud No 103 tahun 2014). Pendekatan saintifik ini merupakan pendekatan yang sesuai dalam pembelajaran sains. Model pembelajaran inkuiri adalah salah satu model yang menggunakan pendekatan saintifik ini. Pembelajaran inkuiri sendiri merupakan pembelajaran dengan pendekatan saintifik yang melibatkan aktivitas berupa observasi, bertanya, membaca dan mencari informasi, menginvestigasi, mengumpulkan data, menganalisis data, memprediksi, menjelaskan, dan mengkomunikasikan hasil (Varma, Volkmann, \& Hanuscin, 2009). Kebebasan mengeksplorasi melalui pembelajaran berbasis inkuiri dinilai lebih efektif dalam meningkatkan kemampuan peserta didik pada bidang sains ketimbang metode tradisional yang menuntut peserta didik untuk menghafal konsep-konsep sains (Maxwell \& Lambeth, 2015).

Selain itu, di era revolusi industry 4.0, melalui pembelajaran diharapkan peserta didik mampu menguasai keterampilan abad 21 yang paling tidak mencakup 4 kemampuan yang dikenal dengan 4C, yaitu kemampuan berpikir kritis (critical thinking), kreatif (creative), kemampuan berkolaborasi (collaboration), dan kemampuan berkomunikasi (communication) (NEA, 2016). Keempat kemampuan tersebut sangat potensial dikembangkan melalui pembelajaran sains dengan pendekatan saintifik.

Untuk menyampaikan pembelajaran sains dengan pendekatan saintifik, termasuk dengan inkuiri, diperlukan media pembelajaran yang dapat mendukung kegiatan peserta didik. Media ini berfungsi untuk menarik minat peserta didik sekaligus untuk menunjukan fenomena-fenomena sains secara konkret pada peserta didik di SD. Media pembelajaran yang menunjukan fenomena konkret diperlukan pada pembelajaran di SD sebab kebanyakan peserta didik di SD berada pada tahap perkembangan kognitif operasional konkret dimana pada umumnya mereka terbatas untuk memikirkan hal-hal yang konkret (Ibda, 2015). Sayangnya, beberapa SD masih masih memiliki keterbatasan ketersediaan media pembelajaran sains yang memadai. Untuk mengatasi keterbatasan tersebut, guru dituntut untuk dapat berinovasi dalam menciptakan media-media pembelajaran sains yang murah dan sederhana, namun dapat mendukung pembelajaran dan mengasah kemampuan berpikir peserta didik. Persoalan lain yang dihadapi di SD adalah beberapa guru SD tidak memiliki latar belakang pendidikan sains sehingga mereka lemah pada pengetahuan teori dan konsep sains. Akibatnya, untuk berinovasi mengembangkan media pembelajaran sains pun mereka kewalahan.

Adanya keterbatasan media pembelajaran sains di SD dan peluang para guru untuk mengembangkan media pembelajaran, mendorong Tim Pengabdian Kepada Masyarakat Universitas Katolik Widya Mandala Surabaya bermitra dengan SD Dapena dan SDK St 
Theresia II Surabaya untuk melakukan pendampingan guru-guru dalam membuat media pembelajaran sains SD. Pada pendampingan ini, para guru juga didampingi untuk membuat lembar aktivitas peserta didik yang dapat digunakan dalam mengarahkan peserta didik untuk ber-inkuiri melalui eksperimen sains. Media pembelajaran sains dan contoh lembar aktivitas peserta didik dalam Bahasa Indonesia dan Inggris yang diberikan pada pelatihan ini merupakan hasil penelitian pengembangan sebelumnya yang telah terujicoba (Herwinarso \& Palupi, 2014)

\section{METODE PELAKSANAAN}

Pendampingan pengembangan media pembelajaran sains untuk guru-guru SD ini diadakan dengan menggandeng dua sekolah mitra yaitu SD Dapenda dan SDK St Theresia II Surabaya. Pendampingan di SD Dapena Surabaya berlangsung pada 30 Juli-8 Agustus 2019 diikuti oleh 8 guru. Sedangkan pendampingan di SDK St Theresia II Surabaya dilaksanakan pada tanggal 26-28 Agustus 2019 dan diikuti oleh 18 guru.

Pelaksanaan kegiatan pengabdian pada masyarakat ini terdiri dari 3 tahapan yaitu tahap persiapan, pelatihan, dan evaluasi.

1. Tahap Persiapan

Tim Pengabdian kepada Masyarakat melakukan observasi terlebih dahulu ke SD Dapena Surabaya dan SDK St Theresia II Surabaya untuk melihat kebutuhan yang ada di sekolah. Selanjutnya Tim menyusun rancangan kegiatan pelatihan, menyiapkan materi, dan menyiapkan alat serta bahan yang dibutuhkan pada pendampingan pembuatan media pembelajaran sains SD.

2. Tahap Pelatihan

Pembagian sesi pelatihan disesuaikan dengan waktu yang memungkinkan dilakukan oleh sekolah dan tim. Pelatihan diberikan kepada guru-guru di SD Dapena dalam waktu 5 hari, masing-masing sesi terdiri dari 2 jam, dengan rincian sebagai berikut:

○ Tanggal 30 Juli 2019, pemaparan dan diskusi mengenai pembelajaran dengan pendekatan saintifik di SD.

○ Tanggal 1 Agustus 2019, pelatihan pembuatan media pembelajaran sains topik Udara.

○ Tanggal 5 Agustus 2019, pelatihan pembuatan media pembelajaran sains topik Listrik.

○ Tanggal 6 Agustus 2019, pelatihan pembuatan media pembelajaran sains topik Energi.

- Tanggal 8 Agustus 2019, pelatihan pembuatan lembar aktivitas peserta didik. Pelatihan pada guru-guru di SDK St Theresia II Surabaya dilaksanakan selama 3 hari, dimana masing-masing sesinya berlangsung selama 3.5 jam. Adapun rincian pelatihan adalah sebagai berikut:

- Tanggal 26 Agustus 2019, pemaparan dan diskusi mengenai pembelajaran dengan pendekatan saintifik di SD dan pendampingan pembuatan media pembelajaran topik Udara.

○ Tanggal 27 Agustus 2019, pendampingan pembuatan media pembelajaran sains topik Listrik dan Energi. 
o Tanggal 28 Agustus 2019, pendampingan pembuatan media pembelajaran topik Energi dan pembuatan lembar aktivitas peserta didik

Untuk mengetahui pengaruh pendampingan ini pada penguasaan guru SD akan konsep sains dan pemahaman terhadap pembelajaran dengan pendekatan saintifik, maka para guru diberi pre- dan post-test sebelum dan sesudah pelatihan.

Hasil pre- dan post-test dianalisis dengan mengghitung nilai $\mathrm{N}$-gain of average melalui persamaan:

$$
\text { gain of average }=\frac{\text { rerata posttest }- \text { rerata pretest }}{100-\text { rerata pretest }}
$$

Nilai $N$-gain kurang dari 0.3 dikategorikan sebagai peningkatan rendah; nilai $N$-gain antara 0.3 dan 0.7 dikategorikan sebagai peningkatan sedang; nilai $\mathrm{N}$-gain lebih dari 0.7 termasuk peningkatan tinggi (Hake, 1998).

3. Tahap Evaluasi

Evaluasi terhadap pelaksanaan kegiatan dilakukan dengan pengisian angket evaluasi oleh peserta pelatihan. Angket evaluasi kegiatan pelatihan yang diberikan kepada peserta berisi beberapa pernyataan, peserta diminta mengisi Sangat Setuju, Setuju, Tidak Setuju, dan Sangat Tidak Setuju. Jawaban angket dikonversi menjadi skor 4, 3, 2, dan 1 kemudian dirata-rata. Interpretasi rata-rata skor jawaban pada angket diberikan pada Tabel 1 .

Tabel 1 Kriteria Nilai Angket Evaluasi

\begin{tabular}{|c|c|c|}
\hline No & Rentang Skor & Kategori \\
\hline 1 & $x \geq 3,0$ & Sangat baik \\
\hline 2 & $3,0>x \geq 2,5$ & Baik \\
\hline 3 & $2,5>x \geq 2$ & Tidak baik \\
\hline 4 & $x<2$ & Sangat tidak baik \\
\hline
\end{tabular}

\section{HASIL DAN PEMBAHASAN}

\section{Pelaksanaan Pelatihan}

Kegiatan pendampingan pengembangan media pembelajaran sains di SD Dapena dan SDK St Theresia II Surabaya diawali dengan pengantar berupa penyegaran materi mengenai pembelajaran dengan pendekatan saintifik, termasuk di dalamnya metode inkuiri pada pembelajaran sains. Setelah pemaparan materi oleh tim, dilakukan tanya-jawab dan diskusi.

Materi utama pada kegiatan pendampingan ini adalah tentang pengembangan media pembelajaran sains SD. Ada tiga tema sains yang dikembangkan sebagai media pembelajaran pada pelatihan kali ini, yaitu tema Udara, Listri, dan Energi. Beberapa media pembelajaran demonstrasi/eksperimen tema Udara yang dibuat adalah mencakup topik:

1. Udara mengalir dari tekanan tinggi ke rendah

2. Udara menempati ruang

3. Udara memiliki massa 
4. Udara mengembang bila dipanaskan

5. Oksigen diperlukan pada proses pembakaran

Gambar 1. menunjukan salah satu aktivitas perancangan media pembelajaran dengan topik udara menempati ruang.

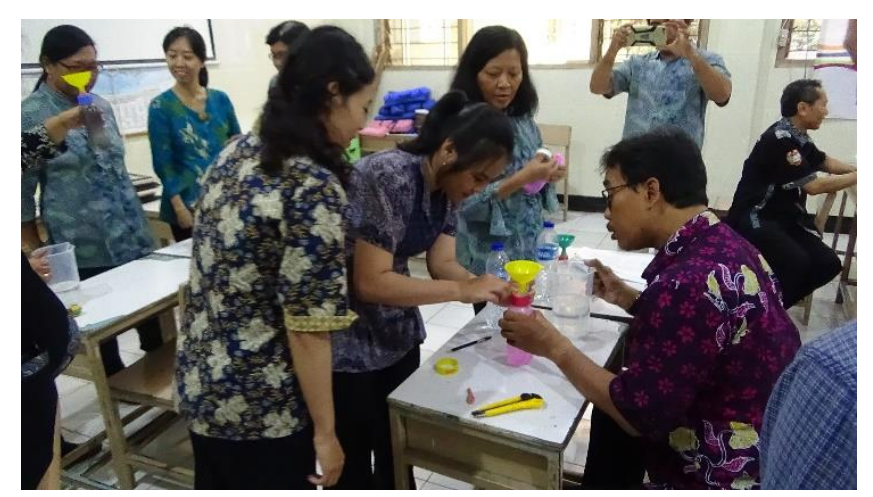

Gambar 1. Para guru di SD Dapena Surabaya sedang merangkai media pembelajaran dengan topik udara menempati ruang

Selain tema Udara, peserta juga didampingi membuat media pembelajaran tema Listrik. Salah satu dokumentasinya ditunjukkan pada Gambar 2. Beberapa topik bertemakan Listrik diantaranya adalah:

1. Rangkaian terbuka dan tertutup

2. Baterai dirangkai seri dan parallel

3. Lampu dirangkai seri dan parallel

4. Konduktor atau Isolator?

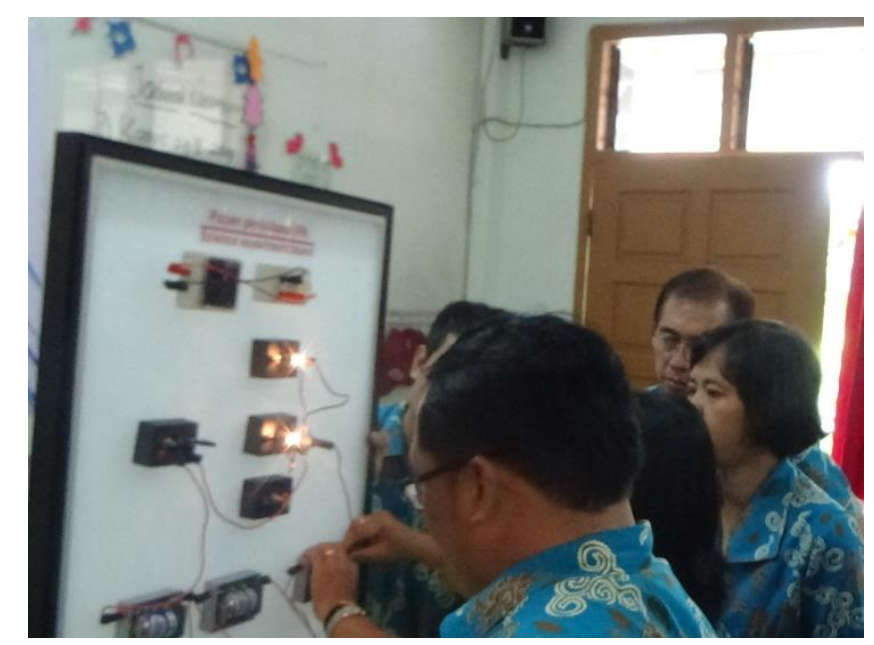

Gambar 2. Para guru di SDK St Theresia II sedang merangkai media pembelajaran dengan topik Listrik

Media pembelajaran dengan tema energi yang dikembangkan pada pelatihan ini mencakup topik-topik sebagai berikut:

1. Perubahan energi listrik menjadi beraneka ragam energi

2. Perubahan energi cahaya menjadi beraneka ragam energi 
3. "Mobil angin", konversi energi angina menjadi gerak

4. "Kincir air", konversi energi potensial menjadi gerak

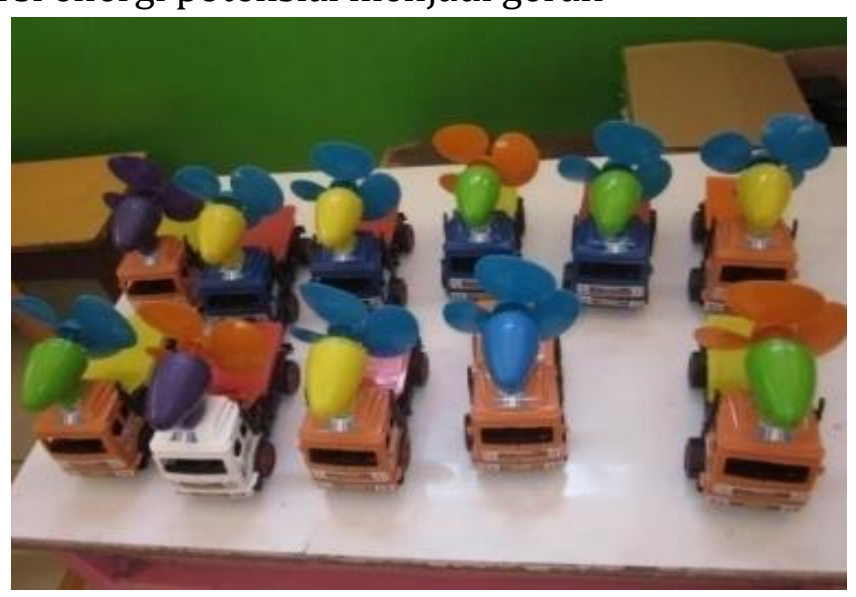

Gambar 3. Salah satu media yang dikembangkan adalah Mobil Angin. Mobil ini memperagakan salah satu pemanfaatan tenaga angin.

Penerapan media pembelajaran dalam pembelajaran sains memerlukan panduan berupa Lembar Aktivitas Peserta Didik. Pada pertemuan terakhir, para guru juga distimulus untuk mengembangkan Lembar Aktivitas Peserta Didik yang bisa merangsang peserta didik untuk berpikir kritis melalui pengamatan atau aktivitas dengan media pembelajaran yang disajikan oleh guru. Pada pendampingan ini, Tim Pengabdian kepada Masyarakat memberikan contoh model yang dapat digunakan sebagai acuan guru dalam menyusun lembar aktivitas peserta didiknya sendiri. Model lembar aktivitas yang dicontohkan pada pendampingan ini disajikan dengan menggunakan dua bahasa (bilingual) yaitu Bahasa Indonesia dan Bahasa Inggris sehingga dapat digunakan guru apabila ingin melalukan pembelajaran secara bilingual.

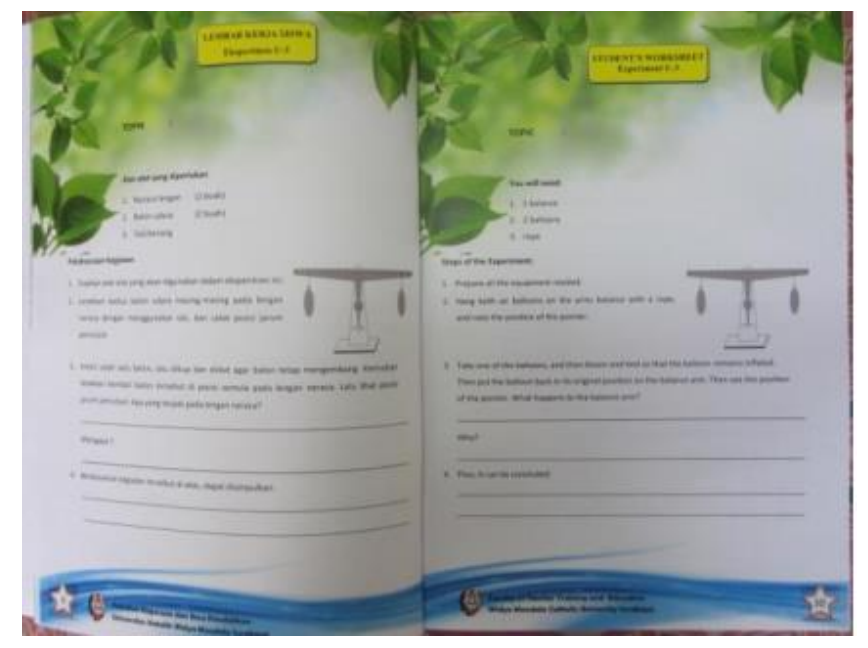

Gambar 4. Lembar aktivitas peserta didik bilingual yang dijadikan model percontohan 


\section{Dampak Pelatihan}

Sesuai deskripsi pada tahap pelaksanaan, peserta diberi pre-test terlebih dahulu sebelum pelatihan pembuatan media pembelajaran sains SD ini dilaksanakan. Setelah pelatihan selesai diberikan, para peserta diminta untuk mengerjakan post-test. Instrumen pre- dan post-test terdiri dari 6 butir soal yang menjaring informasi mengenai pengetahuan guru pada pembelajaran dengan pendekatan saintifik, pengetahuan guru mengenai konsep udara, listrik, dan energi.

Pada pelatihan di SD Dapena Surabaya, terdapat 8 peserta yang mengikuti kegiatan pelatihan ini, tetapi dua peserta tidak mengikuti pertemuan terakhir, sehingga hanya 6 peserta yang menuntaskan pre dan post-test. Sedangkan pada pelatihan di SDK St Theresia II Surabaya, terdapat 13 peserta yang mengikuti yang mengikuti pre dan posttest. Perbadingan rata-rata nilai pre- dan post-test pada kedua sekolah ditunjukkan pada Gambar 5.

Perhitungan gain of average dari pre- dan post-test pada kedua pelatihan tersebut yang dapat dikategorikan sebagai peningkatan sedang (Hake, 1998). Dengan demikian, melalui pelatihan ini pengetahuan guru tentang pembelajaran dengan pendekatan saintifik, pengetahuan konsep udara, listrik, dan energi mengalami peningkatan yang cukup baik.

Berdasarkan observasi yang Tim lakukan, para guru juga antusias dalam kegiatan pelatihan pembuatan media pembelajaran sains ini. Para guru mencoba langsung membuat media-media pembelajaran sains secara berkelompok. Banyak pertanyaanpertanyaan dan masukan ide yang diungkapkan para guru berkaitan dengan pengembangan media pembelajaran sains ini. 
(a)

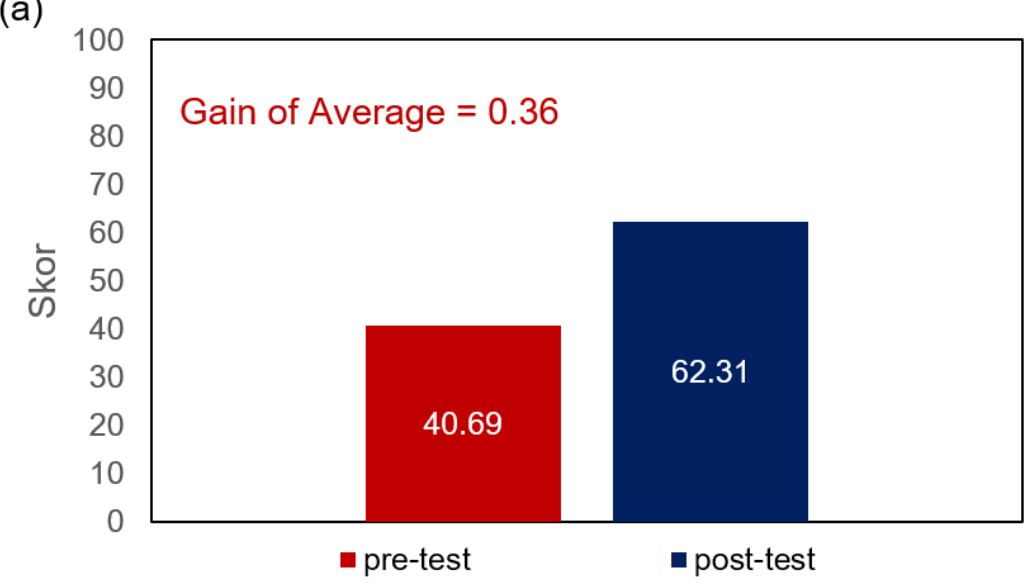

(b)

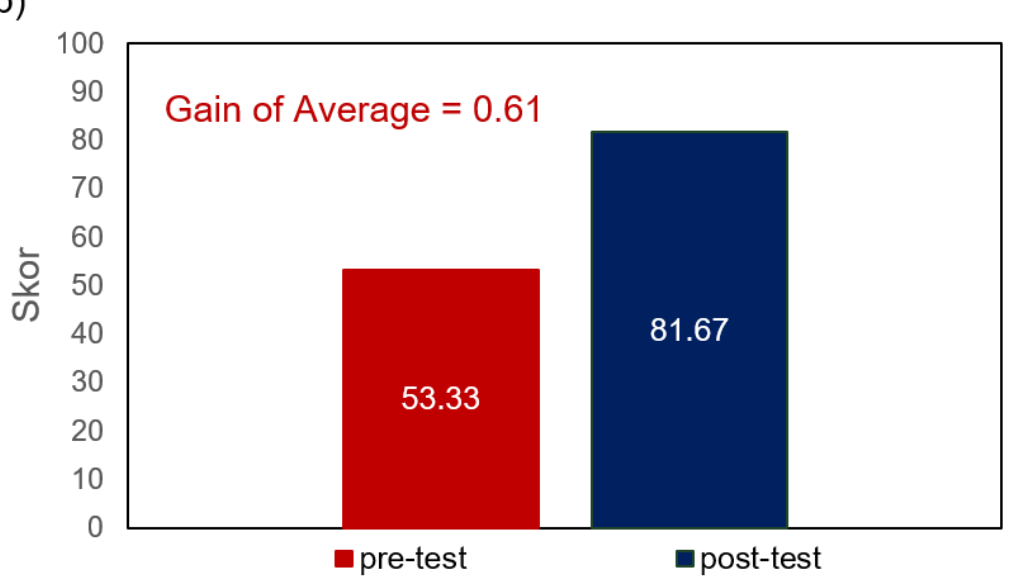

Gambar 5. Perbandingan rerata pre- dan post-test pada pelatihan di (a) SD Dapena dan (b) SDK St Theresia II Surabaya

\section{Evaluasi Pelatihan}

Evaluasi pelatihan oleh peserta dijaring melalui pengisian angket. Angket terdiri dari 12 butir pernyataan, para peserta diminta untuk mengisi respon berupa Sangat Setuju (SS), Setuju (S), Tidak Setuju (TS), dan Sangat Tidak Setuju (STS). Respon SS, S, TS, dan STS ini dikonversi menjadi nilai 4, 3, 2, dan 1 . Hasil rata-rata penilaian oleh guru melalui angket juga disajikan pada Tabel 2.

Secara umum, kegiatan pelatihan ini mendapatkan respon sangat positif dari para guru di SD Dapena dan SDK St Theresia II Surabaya. Para peserta menilai kegiatan pelatihan ini menarik dan bermanfaat bagi mereka dalam pengajaran sains. Selain itu, pelatihan ini memotivasi para guru untuk mengembangkan media-media sains lainnya untuk dapat digunakan di dalam pembelajaran di kelas. 
Tabel 2. Hasil Evaluasi Pelatihan oleh Peserta Pelatihan di SD Dapena Surabaya

\begin{tabular}{|c|c|c|c|c|c|}
\hline \multirow{2}{*}{ No } & \multirow{2}{*}{$\begin{array}{l}\text { Informasi yang dijaring melalui } \\
\text { pernyataan }\end{array}$} & \multicolumn{2}{|c|}{$\begin{array}{l}\text { Hasil di SD Dapena } \\
\text { Surabaya }\end{array}$} & \multicolumn{2}{|c|}{$\begin{array}{l}\text { Hasil di SDK St Theresia } \\
\text { II Surabaya }\end{array}$} \\
\hline & & rata-rata & kriteria & rata-rata & kriteria \\
\hline 1 & $\begin{array}{l}\text { Kejelasan penyajian materi tentang } \\
\text { pendekatan saintifik }\end{array}$ & 3.83 & sangat baik & 3.89 & sangat baik \\
\hline 2 & $\begin{array}{l}\text { Tingkat interaktivitas penyajian } \\
\text { materi tentang pendekatan saintifik }\end{array}$ & 3.83 & sangat baik & 3.89 & sangat baik \\
\hline 3 & $\begin{array}{l}\text { Kebermanfaatan diskusi mengenai } \\
\text { pendekatan saintifik dalam } \\
\text { menambah wawasan baru yang } \\
\text { bermanfaat untuk mengajar }\end{array}$ & 3.67 & sangat baik & 3.67 & sangat baik \\
\hline 4 & $\begin{array}{l}\text { Ketertarikan pada pelatihan } \\
\text { pembuatan media pembelajaran } \\
\text { sains }\end{array}$ & 3.83 & sangat baik & 3.89 & sangat baik \\
\hline 5 & $\begin{array}{l}\text { Kejelasan dan } \text { kemudaan } \\
\text { memahami instruksi dan penjelasan } \\
\text { pelatihan pembuatan media } \\
\text { pembelajaran sains }\end{array}$ & 3.67 & sangat baik & 3.78 & sangat baik \\
\hline 6 & $\begin{array}{l}\text { Peralatan yang dipersiapkan pada } \\
\text { pelatihan pembuatan media } \\
\text { pembelajaran sains }\end{array}$ & 3.67 & sangat baik & 3.94 & sangat baik \\
\hline 7 & $\begin{array}{l}\text { Relevansi media pembelajaran yang } \\
\text { disajikan dengan materi } \\
\text { pembelajaran di SD }\end{array}$ & 4.00 & sangat baik & 3.94 & sangat baik \\
\hline 8 & $\begin{array}{l}\text { Kesesuaian media pembelajaran } \\
\text { yang disajikan sesuai dengan } \\
\text { karakteristik peserta didik di SD }\end{array}$ & 4.00 & sangat baik & 3.89 & sangat baik \\
\hline 9 & $\begin{array}{lr}\text { Kebermanfaatan } & \text { media } \\
\text { pembelajaran yang disajikan dalam } \\
\text { pelatihan }\end{array}$ & 4.00 & sangat baik & 3.89 & sangat baik \\
\hline 10 & $\begin{array}{l}\text { Kebermanfaatan model Lembar } \\
\text { aktivtas peserta didik bilingual yang } \\
\text { dikembangkan }\end{array}$ & 3.67 & sangat baik & 3.44 & sangat baik \\
\hline 11 & $\begin{array}{l}\text { Motivasi peserta untuk menerapkan } \\
\text { pendekatan saintifik pada } \\
\text { pembelajaran di kelas }\end{array}$ & 3.67 & sangat baik & 3.89 & sangat baik \\
\hline 12 & $\begin{array}{l}\text { Motivasi peserta mengembangkan } \\
\text { media-media pembelajaran sains } \\
\text { riil untuk mengajar di kelas }\end{array}$ & 3.50 & sangat baik & 3.78 & sangat baik \\
\hline & Rata-rata seluruh butir & 3.75 & sangat baik & 3.82 & sangat baik \\
\hline
\end{tabular}

\section{SIMPULAN}

Pendampingan pembuatan media pembelajaran sains untuk guru-guru SD telah dilaksanakan d SD Dapena dan SDK St Theresia II Surabaya. Kegiatan meliputi pengantar mengenai pendekatan saintifik, pelatihan pembuatan media pembelajaran dengan tema Udara, Listrik, dan Energi; serta sosialisasi pembuatan lembar aktivitas peserta didik untuk mendukung penerapan media pada pembelajaran sains di kelas. Kegiatan pendampingan ini berjalan dengan baik dan mendapatkan respon sangat postif dari para guru. Selain membuat media pembelajaran secara langsung, para guru juga diberi penyegaran terhadap konsep-konsep sains dasar sehingga dalam pelatihan ini 
pengetahuan guru mengenai konsep sains dasar juga mengalami peningkatan. Kedepan pelatihan semacam ini perlu dilakukan ke sekolah-sekolah lain supaya pembelajaran sains dapat didukung dengan media-media sederhana yang inovatif dan menarik bagi peserta didik.

\section{UCAPAN TERIMA KASIH}

Tim menyampaikan terima kasih kepada Kementerian Riset, Teknologi, dan Pendidikan Tinggi Republik Indonesia yang telah membiayai kegiatan ini melalui hibah Progran Kemitraan Masyarakat dengan nomor kontrak 200AN/WM0 1.5/N/2019 dan kepada LPPM Universitas Katolik Widya Mandala Surabaya atas dukungan yang diberikan.

\section{DAFTAR RUJUKAN}

Hake, R. R. (1998). Interactive-engagement versus traditional methods: A six-thousandstudent survey of mechanics test data for introductory physics courses. American Journal of Physics, 66(1), 64-74. https://doi.org/10.1119/1.18809

Herwinarso, \& Palupi, M. R. (2014). Pembuatan Modul Eksperimen Sains Bilingual untuk Siswa Sekolah Dasar Pokok Bahasan Udara, Listrik, Energi dan Perubahannya. Magister Scientiae, (36), 123-131.

Maxwell, D. O., \& Lambeth, D. T. (2015). Effects of using inquiry-based learning on science achievement for fifth-grade students. Asia-Pacific Forum on Science Learning and Teaching, 16(1), 1-31.

NEA. (2016). Preparing 21st Century Students for a Global Society: An Educator's Guide to the "Four Cs". Retrieved from http://www.nea.org/assets/docs/A-Guide-to-FourCs.pdf

OECD. (2018). PISA 2015 Result in Focus, 5.

Varma, T., Volkmann, M., \& Hanuscin, D. (2009). Preservice elementary teachers' perceptions of their understanding of inquiry and inquiry-based science pedagogy: Influence of an elementary science education methods course and a science field experience. Journal of Elementary Science Education, 21(4), 1-22. 